\title{
ARTICLES
}

\section{An Urban Project in Rural Crisis: Responding to Coronavirus in Bulgarian Villages}

\author{
Sarah Craycraft \\ Ohio State University \\ Columbus, Ohio
}

Abstract

The unprecedented situation of COVID-19 has created a unique response from village-based projects in rural Bulgaria. My research from 2019-2020 followed three projects that facilitate urban-rural intergenerational connection as a form of rural reinvestment. With project planning uncertain and interactions between generations discouraged due to the pandemic, my research, and the cultural work I am following, took an unexpected turn. Rather than fulfilling their core missions of connecting young and old, rural and urban people together to pass on rural culture, these projects transformed their rhetoric and practices to support the elderly in a time of crisis. By drawing on my experiences in the field throughout Bulgaria's early onset of pandemic and lockdown measures as well as "virtual ethnography" (being in the virtual spaces where communication and online events are happening), I explore how two of the intergenerational projects aimed at heritage-based rural reinvestment in Bulgaria have adapted and organized to fill different needs in a time of crisis. During the coronavirus pandemic, these projects served as a well-poised mechanism for responding quickly to shifting needs and contexts.

Introduction

Baba Violeta pats out a smooth, elastic ball of dough on her kitchen table in a northwestern Bulgarian village on 22 March 2020, the first day of spring. (1) She shapes the mass into a flat, thick oval, making two parallel sets of cuts on either side and affixing the strips she created in the center of the shape to form small, doughy arms with clasped hands. She describes the process as she works:

Ето сега ще покажа. Това е едното. Режем за ръчичките. Така така се реже. Ръчичките се свиват. Това е млад ново детенце. Ето го новото начало.

[Here, now I will show you. This is one. We cut it for the arms, like so; like so it's cut. The arms connect. This is a young new child. There it is, a new beginning.] [Rezidentsiia Baba 2020a]

Violeta demonstrates the making of mladentsi [sing. mladenche] - small bread "children" or dolls - to welcome the spring season as part of the Bulgarian ritual 
calendar [MacDermott 1998]. She performs this practice in a three-and-a-halfminute video shared to Facebook in which she exudes a sense of calm reassurance and matronly authority over the kitchen space [Rezidentsiia Baba 2020a]. (2) Though this bread ritual may call to mind similar video clips on YouTube featuring elderly women preparing traditional recipes, this short film stands apart from similar performances due to its context. The video was shared just one week after Bulgarian officials announced a national state of emergency due to the onset of COVID-19 as part of a larger social media campaign in response to the pandemic.

Indeed, Violeta's bread making becomes a background performance in this short film, as the activity provides an occasion for a discussion about the tactics necessary for enduring emergency lockdown. Ivan, a resident of Violeta's village, stands off-screen while filming the process and is heard, not seen, as he asks Violeta to describe her life in the village during the pandemic. She lists practices such as drinking water with lemon and taking vitamins, fishing in the river, working in her garden, and keeping to herself as preventative measures against the coronavirus. She mentions drinking medicine when needed. Ivan jokingly breaks the frame of her recitation, asking if by medicine, she means the homemade liquor rakiia, a source of pride for some Bulgarians, that many claim can kill the virus. Violeta laughingly insists that she does not mean rakiia and returns the conversation to bread making.

Aside from Ivan's joke, the conversation takes a lighthearted but earnest tone as it conveys the serenity, resilience, and sensibility of isolated village lifestyles, which seem to escape the atmosphere of panic caused by COVID-19. Indeed, this video is not meant for other villagers but rather is directed toward an urban audience. Ivan asks Violeta what advice she would recommend to city people without the ability to take part in the practices she describes, and Violeta prescribes that urbanites should leave home rarely, follow the emergency measures set out by the state, and consume thoughtfully, buying only what is needed to ensure that enough products are left on store shelves for others. Villagers have a cellar, she explains, and so they need only buy basic cooking staples. The mladentsi-making, combined with this conversation about health practices, suggests a relationship between folkways and wellness.

This short film clip is notable for a number of reasons. First, we see an annual practice recontextualized during the pandemic. Like many in-person activities, the village's springtime holiday was cancelled, and there would be no gathering in the local chitalishte [cultural center, pl. chitalishta]. The alternative format of YouTube video demonstration provided Violeta a different audience for performing this ritual in the absence of normal contexts. Second, she associates the properties of ritual performance not only with the new beginnings of the seasonal round, but with a new beginning in relation to the current health crisis. The making of a mladenche is a signifier of ongoing ritual practice, in spite of the interruptions caused by the coronavirus, which welcomes viewers into a village home and into the sense of calm contained within. This practice indexes a different sort of rhythm, one of timelessness and the healing that comes, the viewer is asked 
to believe, through connection to folkways. Perhaps most poignantly, the making of mladentsi brought together two generations during a time in which physical connections between young and old, especially those from different communities, was seen as cause for alarm due to transmission risks. The video clip enabled young people to join the practice, if from a distance.

As demonstrated by this short video clip, the threat of viral COVID-19 transmission in face-to-face interactions afforded an occasion for transmission of a different sort: cultural sharing via virtual means. Though Violeta rolls out her mladentsi in front of just one other person, her art is made visible to potentially thousands of viewers via Facebook, not as a stand-alone video shared by her or Ivan, but as part of a larger campaign by an NGO based in Sofia, Bulgaria, Fabrika za Idei [Ideas Factory]. As a part of this campaign, her video joined other short clips, health tips, and updates that were shared during the early weeks of the pandemic. Even before Bulgarian officials declared a state of emergency, the Fabrika za Idei team had ceased visits to villages and had redirected its energies to focus more specifically on the needs of the moment, all the while discouraging the actions that it exists to facilitate-interactions between the young and the old. This team is not alone in reconfiguring trips between city and village; lives around Bulgaria were interrupted as people who normally move between cities and villages were suddenly confined to one place. Mobility is a significant and crucial part of life for many living in Bulgaria, but movement, somewhat ironically, was deemed to be one of the riskiest aspects of life during the pandemic.

Ethnographic Fieldwork

Based on my fieldwork experiences and observations in Bulgaria during the COVID-19 pandemic, this field report explores how two cultural initiatives shifted to the online transmission of ideas and practices when the physical movement of bodies was restricted. Two projects-Rezidentsiia Baba [Granny Residence] and Selo Nazaem [Borrowed Village] - draw upon and foster the intergenerational transmission of folkways as a means of connecting urban young people with elderly village residents. (3) In light of the extreme risk posed to the elderly by the coronavirus, both projects reimagined their work in early March 2020, expanding their foci on cultural transmission to also include elderly care in a time of crisis. Both Rezidentsiia Baba and Selo Nazaem were able to unite and strengthen communities during this period through the exchange of folk knowledge. Contextualizing these responses within a broader landscape of change and spatial renegotiations - online and in-person. I will discuss how the creation of these two social media campaigns echoed larger patterns of response to the crisis.

By moving the space of transmission and exchange online, the projects were able to draw upon already-established networks to highlight the interconnections among vernacular practice, health, and community care. Rather than concluding that the transmission of folklore and folk practice simply "went online" during the pandemic, this article highlights the necessity of prior in-person relations for the 
successful transition to an online environment. These digital connections relied on a preexisting foundation of vernacular practice that had effectively reconnected young urbanites to elderly villagers inhabiting rural spaces.

\section{Background}

To understand the impact of the COVID-19 on village-based intergenerational projects and their various responses, it is necessary to first examine why young, urban people would be interested in village lifeways and why intergenerational programming in Bulgaria generally takes place in villages rather than in cities. Traditionally a space of work and agricultural everyday life, the village has seen a steady decline over the last decades from its thriving status during socialist times. Despite this fact, the village is often conceptualized by those who were born around or after 1989 as a place of play and childhood summertime memories with grandparents. For those lacking an active familial connection to a village, these small communities are often imagined as unexplored, exotic places seen from train windows and understood as an important but residual piece of national collective memory.

Villages evoke different memories for older generations and often connote a backwardness or crudeness that urbanites seek to escape. Drastic transformations of the Bulgarian village throughout the late nineteenth and twentieth centuries, due to industrialization and regime change, have shaped what is often described as a demographic crisis; many villages are now all but emptied of living residents. (4) Indeed, Bulgaria itself ranks as one of the most rapidly depopulating nations worldwide, with a 2019 United Nations report projecting a population decrease of over 1.5 million by 2050. (5) Despite these rates of depopulation, villages have become a surprising site of activity for young, urban Bulgarians. Thirty years after socialism, a noticeable wave of young people is relocating to villages, as well as initiating village-based projects that attempt to direct funds to, increase interaction with, and foster culture and means to secure a livelihood in the Bulgarian countryside. Whereas socialist ideology framed the village as a historically important but backward and anti-progressive element of the Bulgarian past [Kaneff 2004], a growing body of scholarship on the post-socialist village suggests changing attitudes: a subset of the younger generation is seeking deeper connections to rural lifeways and reevaluating rural Bulgaria in the process. (6)

However, that generation's experiences of vernacular practices, and by extension village life more generally, are significantly shaped by socialist reframing. As Silverman [1983: 60] writes in regard to the manipulation and sanitization of village, regional, and ethnic folk practices in Bulgaria during the late socialist period, "A new generation of Bulgarians is emerging, a generation shaped by government-sponsored folklore rather than by village traditions." Citing Kirschenblatt-Gimblett, Valdimar Hafstein [2012: 508] writes that "to possess heritage is to be modern; it is a modern way of relating to the past." Village lifeways were framed as cultural heritage, a tool to catapult socialist Bulgaria's modernization project. The resulting crystallization of national folklore 
during this period positioned village traditions as fading, pre-modern practices. This, in turn, directly shaped the way urban and rural people understand villages and their associated cultural practices [Buchanan 2006]. Some of these crystallized ideas appear to be open for reinterpretation in the present moment.

As such, ideas about village life and traditional practice are mediated for younger generations not just by forms of representation, but by the processes of transition by which those forms and the places they call to mind were shaped. The village that young people remember and/or seek is a different place in many ways than the village that was lived by their parents and grandparents. This manifests in fascinating ways in contemporary Bulgaria. The generational gap in memory between experiences of the socialist village and today's struggling villages creates space in some ways for a particular longing for rural Bulgaria informed by nostalgia, loss, ideology, and memory [Todorova and Gilles 2010]. (7) More recent European Union reforms have further decimated small-scale farming and all but robbed many young Bulgarian villagers of viable livelihoods, with the exception, of course, of the urban-rural commuter-worker [Filak 2015].

Nevertheless, interest in villages abounds. Young activists and enthusiasts I have spoken with often frame the reclamation of village lifeways as repair, in response to cultural and generational breakage inflicted by socialism and a botched transition to democracy. Despite this understanding, they embrace a folk tradition that is a mix of socialist staged performance, pagan and Orthodox practices tied to the ritual calendar, and a growing preference for the domashno or handmade as signifiers of "authentic" folklore and folklife. (8) Layers of what is indexed by "village" overlap to inform a contemporary social imaginary of this space and its associated meanings. (9) The much-discussed topic of depopulation in Bulgaria and the burgeoning investments in rural spaces and practices are contextualized and often inspired by these realities and interpretations of vernacular culture.

Initiatives dedicated to village revitalization span the country. Some are implemented by government institutions, some by grassroots organizations, but all speak to a growing contemporary salience of village life for (re)fashioning broader cultural meanings in Bulgaria. As rural places are reimagined and recreated, the presumed boundary between rural and urban often becomes reified as a boundary between the elderly/traditional and the young/modern, even as young actors seek to rebuild connections across this dichotomy. Interestingly, young people seem not to be abandoning the urban, but rather are creating new pathways and reinforcing connections between places and generations that have slowly eroded since the early twentieth century.

Pandemic in Bulgaria

When Bulgaria entered a national lockdown, I had been living in Sofia and conducting ethnographic research for roughly six months. Having just made it through the slow, contemplative winter season, I was gearing up for the most active part of my fieldwork. Simultaneously, the cultural projects I was following 
were waking up from winter slumber and moving into the annual season of project implementation. Up to that point, I had attended fundraisers and festivals, planning retreats and team meetings, and spent weekends with villagers young and old to acquaint myself with the rhythms of and motivations for these grassroots village residencies.

Across the country, early spring is a time of seasonal thaw; just as garden preparations begin in earnest, spring is also the season in which NGOs move from winter dormancy and reflection into the more active stages of summer planning. In 2020, the arrival of spring also marked the arrival of a new word in everyday conversation, prompting different sorts of preparations - coronavirus. As March arrived, every conversation and lingering decision turned at some point to the threat of this new illness. People were uneasy, wary of close quarters and sneezes in enclosed spaces. Conferences went online, and whole offices chose to work from home out of an abundance of caution. Even before a state of emergency was declared following the first coronavirus outbreaks, COVID-19 had already entered the daily surround.

On 13 March, Bulgaria entered a state of national emergency and the country officially imposed protective measures - restricted border crossings, cancelled bus routes, and limited travel from one's place of work or permanent address, provided one could produce the appropriate documentation. Almost overnight, the importance of location gained new immediacy as citizens chose where to remain for the lockdown period. (10) Some city dwellers chose to relocate with friends or family to village houses as the lockdown measures confined residents to apartments in the urban environment and city and national parks were closed to the general public. (11)

I began to notice subtle changes to the urban landscape as official and unofficial changes arose - a dirty mask smashed into the sludge at the edge of the street, a new toilet paper display at a local café. A mannequin in my neighborhood market [Image 1] and famous statues about the city donned facemasks, while open-access spaces like parks were cordoned off with caution tape.

Stores installed plastic shields at registers and distance markers with corporate logos along the aisleways. Bursts of clapping filled the nighttime soundscape at 9:00 pm each evening, a "thank-you" to overburdened healthcare workers. Someone had laid recently purchased groceries in my building's stairwell to air out. My own apartment transformed into a coronavirus shrine. The entryway shelf was lined with masks, rubber gloves, and rubbing alcohol, and the living room was converted into a home office. It was a time of fearing one's neighbor but also lending a helping hand; fellow apartment residents hung letters offering assistance with groceries in common areas, and bags of bread and jars of fruit preserves were left on street corners for the hungry. 
At the same time that life went indoors, calendars began to explode as virtual concerts and social events began to fill the long hours of isolation. As occurred

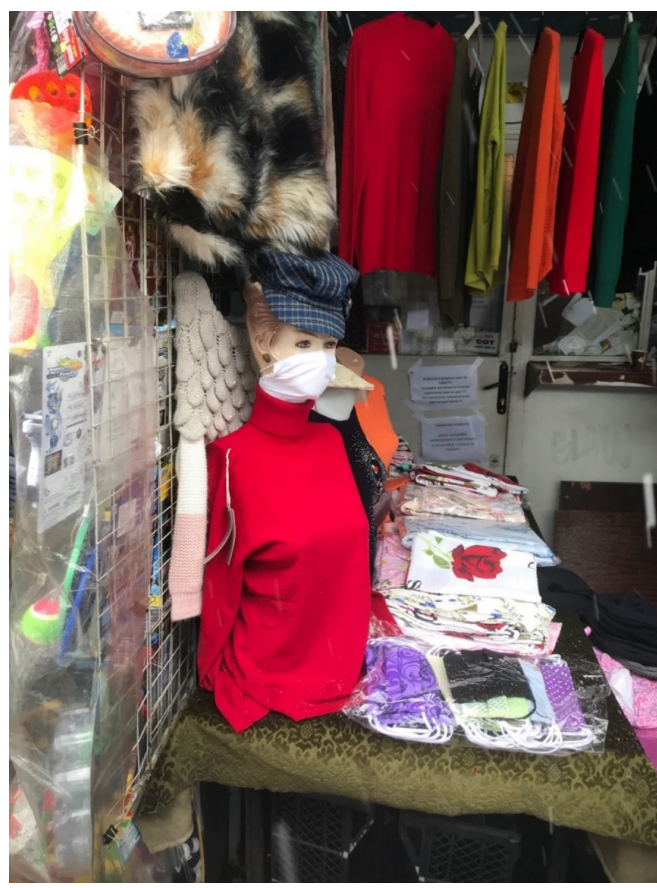

Image 1. A mannequin dons a facemask at Ivan Vazov market in Sofia, Bulgaria [Sarah Craycraft, 2020] elsewhere, the new reality of life online brought with it a massive wave of homemade and handcrafted practices for resisting both the physical and mental torpor of lockdown. As my own research plans were largely suspended, I turned my attention to the changing world around me. Humor, fear, and folklore mixed with skepticism about official action; vernacular responses flourished throughout the emergency situation in Bulgaria. One of my interlocutors, clad in a cooking apron painted to resemble a folk costume, began making traditional recipes like banitsa [cheese pastry] via Facebook Live. Jokes about the potency of the Bulgarian homemade liquor, rakiia, against the virus abounded in casual conversation, meme pages, and even in festival costume as the coronavirus prompted creative adaptations to masqueraders' outfits. The martenitsa, a bracelet given out on the first of March as a token of health and happiness, was invoked as a shield against the virus in various memes and social media posts. Immune-boosting folk remedies were also shared online. One elderly woman even expressed that her community in the Rhodope mountain range was safe from COVID due to the pine trees and clean air.

All the while, the village danced in the background as a topic of conversation and a destination of growing interest. Two key occurrences during the early weeks of lockdown gave rise to the village's prominence in the coronavirus discourse. On the one hand, the urban centralization of resources became woefully apparent, especially after bus routes between cities and villages were restricted or discontinued altogether. Pharmaceutical supplies, healthcare, and other resources were less accessible without reliable transportation to rural areas (many pensioners rely on bus services and visiting relatives to provide their weekly needs). Students living in villages struggled to keep up with school as poor internet connection or lack of devices isolated them from virtual classrooms. 
Likewise, elderly residents without devices were cut off from normal modes of communication with relatives living in cities and abroad, especially those who relied on chitalishte [cultural center] or café internet services to use their cell phones. Thus the interdependency between urban and rural living was made clearer at this time.

In the village, commensal routines such as coffees or beers with friends, or choir and dance practices were interrupted. Urban-rural movement was also highly restricted. On the other hand, many aspects of everyday village life continued as they had prior to the pandemic, albeit with minor alterations to facilitate continuity. (12) For example, one woman in her seventies informed me that the women in her village merely moved their daily café gatherings to her backyard, thereby skirting formal restrictions (somewhat to my dismay). The relative freedom and access to green space in villages also prompted urbanites to book guest houses or obtain special paperwork to ride out the pandemic in a village house, rather than in their city apartments. As a result of coronavirusinduced migration, villages were fuller than usual for this time of year.

With shifts in the use of physical space came shifts in virtual space as well. As I traced the movements of friends and connections who had relocated to villages, I noticed that they were also explaining this choice with moral reasoning, shared online and during our conversations. Cities were overcrowded, unhealthy, and disconnected from lifeways that are vital to a truer existence, went the logic. It was not enough for these young urbanites to take the plunge and physically move, they also had to share about it through social media networks. Roughly a month into the emergency situation, I was added to a new Facebook group where members shared survival tips for and experiences of village living, with the idea of fostering community between village enthusiasts. Some of these enthusiasts had relocated temporarily from cities, some already lived in villages full-time, some had recently made the permanent move, while others merely admired the village from afar. Posts displaying flowers, gardens, and home-cooking were accompanied by self-aware captions such as "taka e na selo" [this is what it's like in the village], or videos explaining why village living is healthier than the urban lifestyle for promoting calmness and safety during the pandemic. A few of my interlocutors viewed this moment as crucial for reframing the idea of village life. One even stated that she believes each person will think more seriously about the village lifestyle after the fear of the coronavirus passes, but that "real village people" do not have time to share pictures of their food online. (13) As I discuss below, these new instances of articulating the village as a pleasant and desirable alternative to unhealthy city life are noteworthy in light of the strategic ideological framing of the village as backward during socialism.

Thus we see that physical and ideological changes to place bled into and shaped virtual spaces as well during the onset of the pandemic. At a time when the fate of Bulgarian villages is already in a state of demographic crisis, a crisis of a different sort brought the village into even sharper focus. This, then, is the context within which the two projects I discuss below, Rezidentsiia Baba and Selo Nazaem, operated. 
Village Residencies Respond to COVID-19

My research traces networks of young Bulgarians who are engaged, in some capacity, in the reframing and reclamation of village lifeways. This is particularly visible in a somewhat new form, residency projects: short-term immersive experiences that allow young, urban people to live temporarily in villages around Bulgaria. These curated forms of (re)attachment to place are responses to a complex set of interactions between urbanization, industrialization, depopulation, and ideological manipulation, which have fueled rural depopulation, among other impacts. My fieldwork followed three residencies, though I became aware of others during my research. I discuss two of these residencies in this paper.

Each year in late summer, elderly hosts (almost exclusively women) open their homes to participants, temporarily welcoming new life into villages for the duration of these intergenerational residency projects. Participants learn traditional recipes, interview local residents, and document folk practices like canning, weaving, and folk singing. While some of these practices are living traditions, others are resurrected merely for the purpose of demonstration. Most importantly, different generations spend time together, often creating festivals or large final events to mark the end of the experience, complete with folk costumes and horo [line dancing]. Each project is enacted in a different way and at different scales, though all are facilitated by larger umbrella organizations. Founded in 2015, Rezidentsiia Baba is one of many projects hosted by Fabrika za Idei. All over Bulgaria, participants in this project undertake ethnographic documentation and relationship building for roughly one month, guided by principles of social innovation, design thinking, and transnational skill-sharing [Stoianova 2016a, 2016b].

Selo Nazaem has taken place each year since 2016 in a single village, facilitated by the staff of the Dolni Vadin chitalishte [cultural center] on the banks of the Danube River. The project compliments other programming of the chitalishte, whose primary purpose is to support the needs of community members. Though Selo Nazaem places more emphasis on pre-organized experiential learning and is shorter in duration (roughly one week in length), both programs view reconnection to village life as a path toward healthier, more fulfilling lifestyles and a necessary experience for Bulgarian well-being [Radulova 2020]. (14) Below, I discuss how these projects have built upon their networks and accumulated wisdom to support the communities they work with during the pandemic, despite lockdown measures.

\section{Rezidentsiia Baba}

In early March, the communication strategies for Rezidentsiia Baba began to change. Typically, followers of its work are kept informed of project timelines, results, and upcoming programming through Facebook and Instagram posts as well as by updates to the project website. These informative posts are interspersed with content that was collected by participants over the past five years and shared 
as glimpses into the Rezidentsiia Baba experience and its growing archive. For example, interesting snippets from interviews or photos of young people learning crafts offer followers a small experience of the annual residencies.

Just before the declaration of the national emergency in Bulgaria, Rezidentsiia Baba's posts took on a dual purpose, to convey folk remedies and wisdom associated with the village lifestyle and also to appeal for help in addressing the interruptions of typical resource distribution pathways to villages. With interruptions to weekly trips between cities and villages, new modes of resource distribution filled these gaps. Additionally, videos from elderly residents, like the example above from Violeta, shared updates on rural experiences of the pandemic and fostered a connection to villages that many urbanites could not access from their city apartments. The captions framing these videos prompted followers to learn resilience from elders. Posts featuring herbal remedies promoted natural preventative medicine and connection to the environment for strengthened immunity. For example, the image below explains uses of the leaves and roots of hryan [a horseradish varietal], documented by a participant during one of the Rezidentsiia Baba cycles. The caption of this infographic asks followers to share other immune boosting plants that they have learned about from elderly relatives.

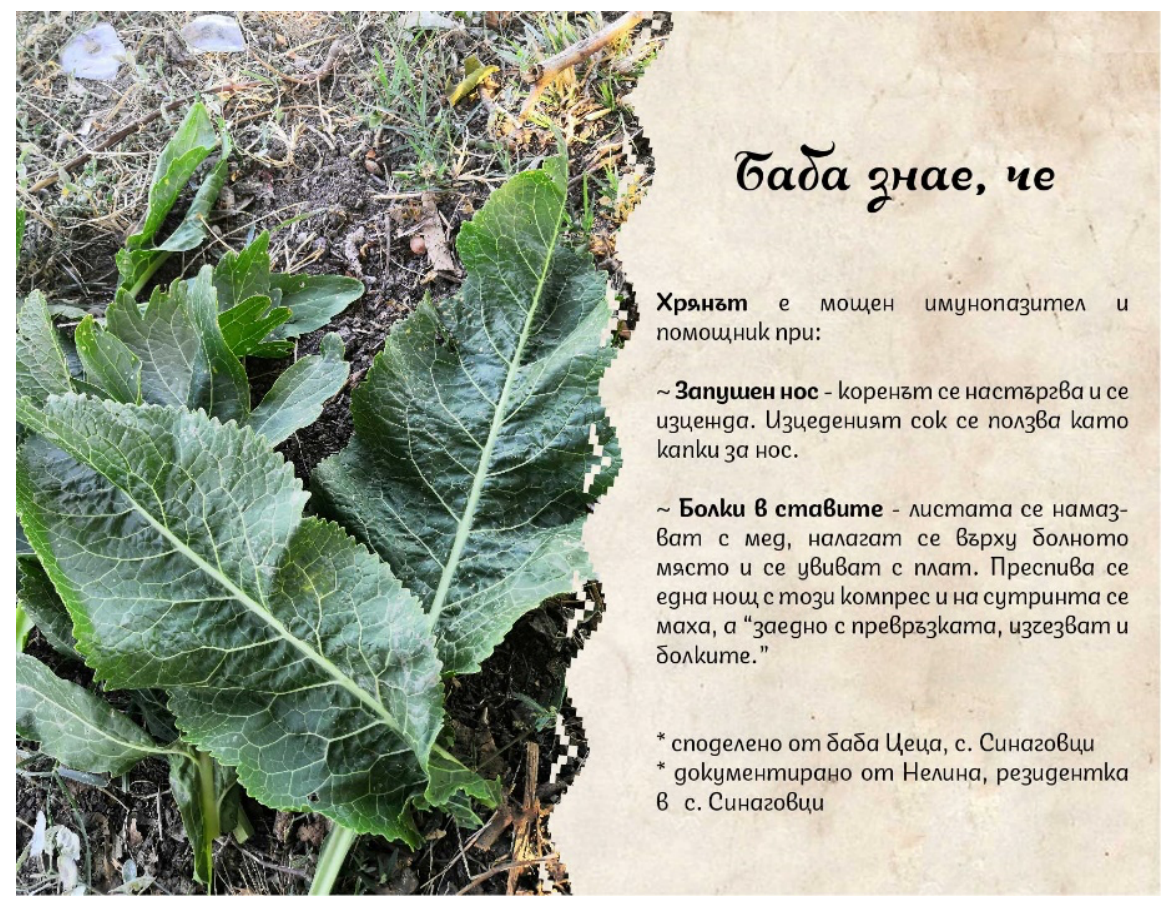




\section{Baba [granny] knows, that...}

Horseradish is a powerful immune booster and helper for:

- A stuffy nose: the root can be grated and squeezed. The squeezed juice can be used as nasal drops

- Joint pain: the leaves can be smeared with honey, applied to the affected area and wrapped in cloth. Sleep one night with this compress and remove it in the morning, and "along with the bandage, the pain disappears."

Shared by Baba Tsetsa, village of Sinagovtsi. Documented by Nelina, resident in the village of Sinagovtsi [Rezidentsiia Baba 2020c]

Not all of the posts and actions taken during the emergency situation involved folklife. In fact, much of Rezidentsiia Baba's work during this time left ethnographic sharing behind almost entirely as the team shifted its day-to-day activities to outreach and resource redistribution. This work depended heavily on the team's already-existing resource bank of grassroots networks, relationships to villages, and practical experience; the knowledge the team has accumulated throughout their five years of practice exceeds the folk songs, audio clips, recipes, and photographs recorded in the Rezidentsiia Baba archive. All of my interlocutors, including team members, reported learning more about the needs of villages through participation in this project. Pandemic interventions drew upon these years of learning.

Having already established strong relationships based on years of studying village traditions, the Fabrika za Idei team and past participants communicated with the elderly to inquire about their needs in this new situation. Rezidentsiia $B a b a$ 's plans for the 2020 program were cancelled and, with donor permission, funds were rerouted to purchase medication and pharmaceutical supplies for elderly villagers. As with most NGO projects, Rezidentsiia Baba followed its action with reports and demonstrations for online followers, sharing the narratives of their work during the early weeks of the lockdown. The project's Facebook feed featured photos of facemask-wearing mayors handing pills to elderly women and of cars packed full of supplies ready to be shipped from the city to the village. Used digital devices such as mobile phones and tablets were also collected and sent to villages for the elderly and students. As one team member stated, their work was even more intense during this period than before the pandemic. (15)

Because Rezidentsiia Baba's activities already involved staying in touch with village hosts even after the residencies ended, it was quite natural to check in on contacts from past cycles. With these networks in place, team members were able to draw on what they had learned about rural marginalization, cultural breakage, and loss of place to reorient their mission and to convey advice to followers. This is seen most clearly in a series of five infographics featuring health 
tips that recommended adjustments to intergenerational interactions during the pandemic. This short series of posts featured cream-colored backgrounds with a colorful folk element stretched across the top of the graphic flanking the words aktsia zdrave [health action] and a prescriptive message in the center. The posts shared tips to care for at-risk elders and chronically-ill relatives, giving suggestions such as organizing trips to the pharmacy on their behalf, warning grandchildren not to visit $b a b a$, donating rubbing alcohol for use in villages, reminding grandparents to self-isolate, avoiding city transport, and paying bills online.

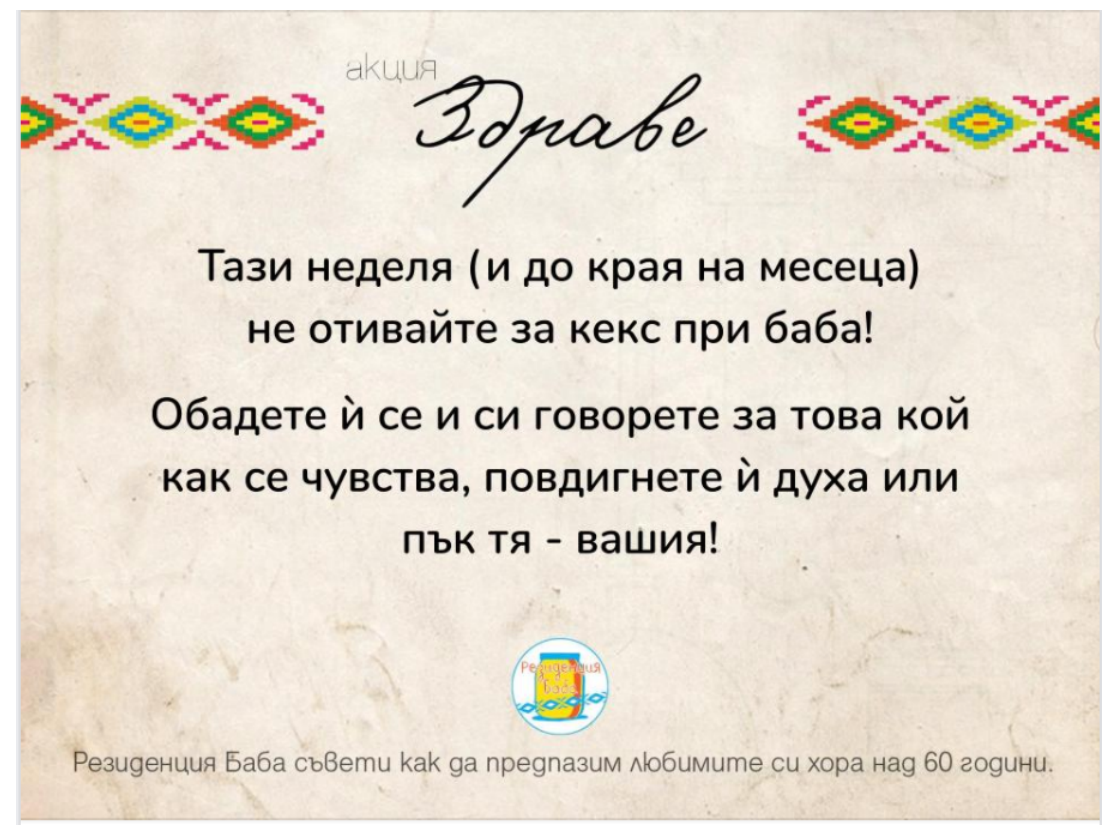

Health Action

This Sunday (and until the end of the month) do not go for cake at baba's!

Call her and talk to each other to hear how you both feel, lift her spirits or, on the other hand her, your own!

Rezidentsiia Baba Tips - How to save our loved ones over 60 years old

[Rezidentsiia Baba 2020d] 
As can be seen in these graphics, a fascinating component of Rezidentsiia Baba's emergency work involves the ways in which online audiences are positioned in relation to both the elderly and to place. The experience of life in a specific village was often scaled up in their messaging to index village life in general: the village is a place where people know how to live calmly, in close relationship with the environment, removed from urban panic. Baba, too, is framed not just as a singular person but as a generalized figure for whom all must care, yet also to whom all can look for an example of resilience and mental strength. These depictions and the interconnections towards which they gesture form the foundation of Rezidentsiia Baba's response to the pandemic - bringing health, ideas about village life, and elderly wisdom into conversation. Followers are asked to take responsibility for the elderly, but also to learn from them.

Indeed, in the same way that Rezidentsiia Baba served the elderly, so too did the elderly help to calm urban project workers. (16) Several posts explain that the team members looked to older village residents for reassurance during the national emergency, even as they had directed care and resources to the villages. This dual positionality is reflected in the content shared on their Facebook page featuring the elderly village women who participated in Rezidentsiia Baba. The team's social media presence assumed an active, knowledgeable stance regarding how the group's followers should interact with villagers, while simultaneously displaying a certain degree of vulnerability in comparison to the capability of elderly villagers; Rezidentsiia Baba regards these elders as resilient in spite of their marginalization. For example, Baba Vasilka, a residency host, states in a video that despite being elderly (and thus at higher risk of infection), she is more worried about young people's ability to cope with the lockdown and the pandemic. (17) She recommends trud [hard work] in the garden or yard, if possible, to take one's mind off of sickness as hard work facilitates life. Likewise, the caption accompanying Violeta's aforementioned mladentsi clip reads as follows:

Оказва се, от разговорите ни с тях до, момента че са много поустойчиви психически от нас и способни да действат градивно и умерено. Като че ли е по- разумно да се обърнем към тях за съвети що е то устойчивост в извънредно положение.

[It turns out, from our conversations with them until now, that they [the elderly] are much more mentally stable than us and are able to act constructively and moderately. It seems more prudent to turn to them for advice on what emergency resilience is.] [Rezidentsiia Baba 2020b]

The project's Facebook posts (including captions and video/photo content) demonstrate a balance between these two positionalities, as can be seen through a close reading of the rhetorical tools used to convey Rezidentsiia Baba's messaging. Wellness tips collected from elderly villagers ("Baba knows, that..."), 
written in a conversational tone, present the information as everyday knowledge shared in a casual and friendly manner from baba to the team or resident and, finally, to the follower.

Coupled with captions like that above, which express that Rezidentsiia Baba is taking its lead from the elderly rather than prescribing action, these choices amplify the advice of the elderly and simultaneously serve to protect them from urban visitors. In this way, the Rezidentsiia Baba team achieved a rhetorical shift from knowledgeable project facilitators to open learners as it looked to the elderly as guides for navigating this period. Rather than reading this position as an abrupt departure from Rezidentsiia Baba's prior encouragement to visit villages, this shift conveys a subtle but sensible reiteration of their messaging - if residency participants desire to gain insights from village life, part of that process involves taking seriously the needs and perspectives of village residents. This stance echoes the project's overall philosophy for social change as well. In their regular programming, the team prioritizes and teaches participants to engage in careful listening before action to understand village resources and needs. This is a method they have honed over time, with each cycle of the residency. (18)

Over the course of the national emergency Rezidentsiia Baba essentially redistributed wellness by drawing on its varied connections to village lifeways. The team's authority to give and request advice is backed by a range of sources: folk wisdom collected and archived over the years; medical and practical advice gathered from news briefings; conversations with people on-the-ground (mayors, village and regional chitalishte directors, local residents), past participants (some of whom are also in contact with their village hosts) as well as with donors, supporters, and other culture workers. Their connections to these sources are portrayed via social media, as followers are introduced to a range of actors: photos of (masked) team members holding or transporting medical supplies; village contacts (mayors, chitalishte staff) distributing vitamins sent by the team; the elderly receiving supplies or narrating village life, etc. Videos featuring the elderly recount how gardening and difficult work can calm and distract people from fear, and captions act as framing devices that call for slower living, closer listening, and quietness as village practices that urban residents can emulate. In sum, Rezidentsiia Baba frames experiences and perspectives from village living as tactics for resilience that can guide life during the pandemic despite one's location, invoking both state of mind and practice as prescribed by elderly residents.

Of course, it is highly likely that many young followers have grandparents, friends, or relatives living in villages and could hear about village conditions directly from them. However, as a voice of authority with years of experience, the Rezidentsiia Baba team was able to create an online space of sharing and exchange that put traditional practice into current context and quickly enabled mutual aid through informal networks. This resource is especially notable when considering Bulgaria's institutional failure to address the impact of this crisis on peripheral spaces in a timely manner. (19) In comparison to the more humorous memes and social media statuses about coronavirus that I discuss above, 
Rezidentsiia Baba's social media presence is earnest and even reverent in its reference to folkways. By sharing video clips and images of practices like the rhythmic kneading of bread, the washing of an old enameled pot in an outdoor garden sink, listening to a folktale, or asking neighbors what they need, Rezidentsiia Baba frames and promotes such practices as a particular kind of alternative response to the coronavirus pandemic rather than the more common flurried and urgent responses.

\section{Selo Nazaem}

The approach to pandemic intervention exhibited by Selo Nazaem also incorporates tactics of multidirectional listening and sharing between villagers, project organizers, and residency participants. For many villagers living in Dolni Vadin - a "village without an exit" at the end of a road to the Bulgarian-Romanian border-life can be solitary. The children and grandchildren of most villagers reside in cities or live abroad, and their peaceful community of less than 150 residents (roughly $90 \%$ of whom are pensioners) is not exactly a destination for many. (20) For a growing group of young urbanites, however, this village on the periphery has grown in relevance. The project Selo Nazaem provides a glimpse of what aid can look like when manifested from within a community and how connections to a network across Bulgaria reduced some of the additional isolation of this crisis beyond that produced by daily life for the elderly.

The impetus for the first cycle of Selo Nazaem in 2016 grew out of the main focus of the chitalishte of caring for village residents, as project co-founders Anelia Spasova and Nina Borisova explained in an interview with the popular Bulgarian series Da khvanesh gorata [To Catch the Forest] [Shturrbeva 2020]. (21) As the secretary and librarian (respectively) of the chitalishte, they view their main responsibility to be community care, with a focus on cultural activities. Selo Nazaem is one such activity, which fills a void in the community each yearintergenerational interaction in the absence of grandchildren, most of whom live abroad - by hosting young, urban visitors in the village. Its primary goal in the new emergency situation, however, was the preservation of life.

In the interview with Da khvanesh gorata, Anelia asked young people to avoid visits for the time being, to preserve the health of at-risk villagers. This message was later reiterated on their social media accounts. As residents of the village themselves, Anelia and Nina found new ways to support the community even as in-person cultural programming took a back seat. Due to the lockdown measures and uncertainty about the duration of the coronavirus threat, the Dolni Vadin chitalishte closed temporarily in mid-March, along with other chitalishta around Bulgaria. Anelia and Nina's work shifted from planning a cultural calendar to distributing medicines, books, and groceries to village pensioners. As they explained it, this was just a continuation of their care work [Katracheva 2020; personal communication].

Similar to Rezidentsiia Baba, part of Selo Nazaem's intervention involved reimagining the networks and spaces it had created online to facilitate new modes 
of intergenerational exchange. Anelia and Nina quickly moved the Selo Nazaem program up a few months to take place during the emergency situation, calling the 2020 cycle "Selo Nazaem - Na Edin Klik Raztoyanie" [Borrowed Village One Click Away]. As one elderly villager put it, the annual residency makes life "not grey anymore." (22) Thus, a continuation of the program in a new form filled a psychological and emotional need during the crisis. This online version amplified some of the aspects of past iterations that had developed over the years. The first year of Selo Nazaem, for instance, was heavily focused on village heritage. The residents performed rituals, made homemade recipes, and learned folk songs and dances to understand aspects of what life in the village is about. The following cycles built on this first year to include more volunteer service, interaction with a wider range of villagers, and even the transmission of knowledge from young to old such as composting demonstrations and medical lectures. The online residency built on this two-way transmission and featured a familiar cast of performers that villagers had already gotten to know in previous years.

Past participants prepared short performances to share online with viewers in Dolni Vadin. They posted home videos of craft-making in Varna, baking in Sofia, and herbal medical knowledge demonstrations from Pleven. Others sang folk songs, recited poetry, and read story books. Library outreach is a critical service provided by the chitalishte and these performances brought storytelling to life at a time in which the library was less active. Anelia and Nina also assembled short films about holiday rituals that occurred during lockdown, allowing for online distanced gatherings to celebrate these holidays. "Grand master" video clips recorded in the village and presenting villagers demonstrating folk arts were also shared for Facebook followers. (23) Although few of the elderly have tablets, smart phones, or computers, Anelia and Nina ensured that community members would have safe options to view the videos. Some went to the chitalishte in small groups of two and three to watch the clips. In cases where elders were unable to leave their homes, the two women made home visits and played the videos on their own devices. (24)

In this way, the typical transmission of village lifeways from the old to the young was reimagined, with young participants sharing performances to interrupt the isolation of elderly village residents and elderly participants sharing their lifeways with a broader audience. Interestingly, some of the young participants shared performances more typically associated with the village or the elderly, such as those featuring folk song and herbal demonstrations. This disrupted some of the tropes regarding which customs belong in cities and which in villages. The circulation of such practices around Bulgaria brought visitors into the homes of viewers each week and placed a marginalized community at the center of nationwide cultural exchange. 


\section{Conclusion}

The adjustments to the programming of Rezidentsiia Baba and Selo Nazaem during the pandemic demonstrated a myriad of responses in reaction to an unprecedented moment. What can the adaptations of village residencies tell us about the turn to folklife in response to the coronavirus pandemic?

First, we can consider the ideas of preservation and transmission present in both projects. Before COVID-19, the work of Rezidentsiia Baba and Selo Nazaem was centered on the preservation of villages and the transmission of village lifeways to young people in response to a different crisis: village depopulation. The switch to emergency action emphasized the preservation of human life and brought new prominence to easy-to-overlook but important distinguishing factors between living folklore and heritage. Although aspects of regular programming from both projects involve the detachment of practices from context or their revival simply for the sake of demonstration, other components emphasize the necessity of exchange and circulation as crucial elements of what keeps a tradition traditional-movement and variation shaped through performance [Ben-Amos 1971, Toelken 1996, Noyes 2016]. In their attempts to prevent coronavirus transmission while continuing on with their vital work, Rezidentsiia Baba and Selo Nazaem utilized new technologies for sharing information, entertainment, and resources.

In this way, selective transmission of folkways online was tailored to fit the current moment and gave performers and audience members a reason to adapt practices to the constraints of the occasion. Though I cannot speak to whether these posts actually caused a follower to knead dough or rush to create an herbal remedy, we all know someone who baked homemade bread for the first time during lockdown. Posts like those shared by Rezidentsiia Baba contextualize the sudden impulse to "make" within larger annual rhythms and systems of belief, grounding the anxieties of the moment in cultural practice. Videos shared through Selo Nazaem prompted participants to select something from their repertoire of skills that would be relevant for their audience in a moment of isolation and detachment. Thus, we see the folk process at work.

The role of the archive, too, adds another important layer. Throughout my fieldwork, I asked different team members at Rezidentsiia Baba why cultural documentation and archival curation were central parts of the residency projects. I never received a clear answer; although preservation was an important component of their work, the relationship between preservation and village revitalization remained ambiguous, even for the team members. Though carefully organized according to year, village, file type, and sometimes genre, their archive exists in what Stewart [1991] calls fragments: decontextualized bits of folklife that at some point struck a project participant as folklore, worthy of documentation. The typical Rezidentsiia Baba Facebook posts present these items to an enthusiastic audience who have opted into weekly doses of village life.

I recall being fascinated by a casual moment in early March in which my roommate, the face behind Rezidentsiia Baba's social media presence, told me 
she was sharing some archival material that dealt with health matters because of rising concerns about the coronavirus. In a moment of crisis, she had turned to the group's archive to make sense of it, using folk wisdom shared with the group's followers. Perhaps an answer to "why document?" in these projects is more complicated than salvage ethnography. Without necessarily knowing it, team members and participants were collecting and saving folklife for a rainy day, such as the situation presented by COVID-19. Placed within the broader scope of reframing and reclaiming villages in contemporary Bulgaria, these practices align with other trends toward a preference for the handmade, seeking alternative lifestyles, and finding a role for the past in the present. As mentioned above, this archival sharing geared toward urban viewers was part of a larger strategy that included turning to and incorporating the perspectives of the rural elderly (especially women) in pandemic-related communications. Thus archival findings joined a multi-directional exchange of advice and experiences, to open up the typical use of Rezidentsiia Baba's social media platforms.

We can also consider the encounters and spaces created by these initiatives, as well as the impacts on how space is regarded more generally. Performances of all kinds allowed for glimpses into kitchens, bedrooms, and gardens. Pensioners in villages spoke directly to urban dwellers, while young people addressed village residents and other project participants, all scattered across Bulgaria. Everyday spaces became zones of play and creation [Abrahams 2005], unique stages for performance in front of an imagined group that expanded the scope of daily life, already made strange by national emergency. These practices were, of course, geared specifically toward communities bounded by online membership in public groups, but actions like sharing videos or playing them in front of family members in the home potentially stretched the audience and allowed them to contribute to the growing online space given to villages at this time. The move to a virtual space was not just a temporary remedy or new avenue for transmission, but rather created a new context as well as a tightening and focusing of the motivations for sharing between generations.

The social media campaigns discussed in this article emphasized villages and their residents as resources and, simultaneously, as spaces and people in need of resources. They demonstrated the relevance of place to the experience of pandemic as well as the affordances and drawbacks of one's location to offering meaningful support. Rezidentsiia Baba and Selo Nazaem provide lessons from two positions with the facilitators of one project located in a city reaching out to villages, and the other located in a village, drawing the resources and people from the city toward locals from within. Anelia and Nina, as staff at the chitalishte, are the sort of people the team at Rezidentsiia Baba liaised with in order to accomplish their network-sourced distance emergency support. As on-the-ground locals who can ensure supplies and cultural exchange are accessible to the elderly, they are necessary links in the chain of resource decentralization, as are the urban organizers on the other end. These two examples raise a question about the potential gains of collaboration between actors working out of different locales what would happen if such efforts joined forces? 
As yet another layer of issues connected to place and positionality, we can consider how the idea of the village and the folkways ascribed to this space as a social imaginary served as a resource. Discourses on the potential role of contemporary villages range from arguments about quality of life, to village practices as desperately needed resources for a potentially grim future. The village as a site of potentiality has a longer history in Bulgarian collective memory that rose to the occasion of the pandemic. Whereas connections to villages offered a means for survival during the financial crisis of the late 1990s to provide access to food and resources in a moment of dire scarcity, the contemporary desire for reconnection to rural Bulgaria by younger generations prompts forms of experimentation in which art and culture are tools for a different sort of survival. (25) Further investigation might consider the connections between these ruralurban interdependencies in times of need.

Finally, the importance of community care during the pandemic warrants attention. The enhanced focus on elderly care during this period necessitated a shift in the positioning of both projects (most clearly Rezidentsiia Baba), as both requested that young people living in cities avoid visiting elderly villagers despite the importance they place on interaction between generations. Although this course of action was mandated by the state, given the high risk to elderly populations, it is noteworthy that these two residencies not only followed state recommendations by discouraging village visits, but followed up with new forms of care. In the case of Selo Nazaem, elder care was already a priority, as Anelia and Nina view their work for the chitalishte to encompass community care. They had identified intergenerational interaction as an element of this care and, as such, the choice to expand to online connection was a sensible adaptation. By structuring the sharing as two-way, they met the needs of community members and young urban people, moving their programming up from late summer to midspring to fill a collective void. Relatedly, Rezidentsiia Baba expanded its central focus from addressing a need for rural connection to centering the needs of village elderly. A balance between rural and urban needs has always been crucial to its programming, as demonstrated by the entrepreneurial components of its residencies, which encourage participants to develop programs that source funding to villages as part of the experience. The pandemic appears to have crystallized or synthesized this outreach in a new way and to have made more space for the voice of elderly villagers in the process.

By drawing on pre-existing networks, these projects-themselves precariously positioned due to funding scarcity-were able to support communities in a time of crisis, and both strengthened and united through the sharing of folk knowledge. Their quick action and interdependency on preexisting networks demonstrate several roles for cultural work in times of crisis and provide models for enacting care based on these relationships. 


\section{NOTES}

$1 B a b a$ is the kinship term for grandmother. It also connotes a more personal or affectionate dimension when used to address elderly women that extends beyond kin relations. When speaking about these women in English, Bulgarians often use $b a b a$ or translate the term as the English diminutive "granny." When naming specific elderly women involved with the intergenerational village residencies, I keep with these practices. I use the more general category of "elderly" to denote specific groups of pensioners living in villages where my fieldwork took place. Although these collectives include men and women, more often than not elderly participants are women. When apposite, I specify some groups specifically as "women pensioners."

2 I am grateful to Theodore Charles for helpful discussions about the place of ritual bread making and domashna rakiia in coronavirus discourse. Theodore's dissertation [forthcoming] addresses these topics more thoroughly [see also Rezidentsiia Baba 2020].

3 I employ 'project' to signify precariously funded initiatives that cluster around a particular topic, theme, or goal, in this case projects that strive toward village revitalization in some fashion. I draw on the writings of Bendix, Bizer, and Noyes [2017], who articulate the "interdisciplinary project as a social form" and "a hybrid, with both the limitations and the affordances of that condition" [1,5].

4 The edited volume Global Villages: Rural and Urban Transformations in Contemporary Bulgaria [Duijzings 2013] provides a thorough overview of transformations to Bulgarian villages. The volume presents "ethnographic accounts of global processes in specific rural places without losing sight of urban contexts" [1]. It makes the insightful argument that spatial connections have long been larger than local, refuting the popular claim that Bulgaria has historically been a "small nation of small peasants" [5]. In the volume, anthropologist Deema Kaneff argues that the relationships between cities and villages in Bulgaria result from and are shaped by globalization - they do not fall along a stark dichotomy of rural versus urban, but are rather fluid.

Continuing waves of transition in Bulgaria give the sense that villages and rural life are anything but stable and timeless. As Bulgarian provincial artisan markets for the Ottoman Empire disappeared with the empire's collapse, postOttoman economic decline led to a surge of village repopulation as artisans lost their trade market and turned to agriculture in the late nineteenth and early twentieth centuries. Pre-socialist land redistribution during the Stamboliiski years (1920s) reconfigured village life, family make-up, and understandings of the rural as the ideal national past. These impacts continued through socialism with the shift from agrarian to industrial Bulgaria [Duijzings 2013; Creed 2013; Neuberger 2013]. The redistribution of young, educated people to villages as per communist work assignments further reconfigured family ties to place. Although contemporary village depopulation is certainly connected to continuing industrialization and urbanization after socialism, these trends began considerably earlier, impacted by each wave of transition. What more, as Gerald Creed [1998] 
demonstrates in Bulgaria and Katherine Verdery [2003] in Romania, the process of de-collectivization during the transition to democracy did not yield a return of young people to villages but rather the opposite-young families stayed in the cities where they had settled.

5 United Nations World Population Prospects [2019] positions Bulgaria as one of the most rapidly depopulating nations worldwide. Further population data can be traced via the annual Population and Demographic Processes reports published by the Bulgarian National Statistical Institute [Stoyanova et al. 2020].

6 Petya Dimitrova [2019] explores urban-rural internal migration and Gavrail Gavrailov et al. [2016] draw on the rising interest in villages to suggest tourism opportunities as one form of village revitalization. The research teams Smelo na Selo [Brave the Village] and Zhizneni Prekhodi Transformirashtoto Selo [Life Transitions in the Transforming Village] explore village transformations more broadly. Reports on the progress of their research can be found at Brave the Village [n.d.] and The Village in Transition [n.d,] respectively.

7 Following Mary Bucholtz [2002: 528], I draw on the sociolinguistic concept "shifter" to signify an understanding of age as myriad and relational, defined in and by context. That is to say, my use of "young" and "old" or "elderly" follows the patterns of usage my research suggests - that the meaning of these words shifts according to context. A 50-year-old woman living in a village might be considered young or old, depending on who else is present with her in a real or imagined context.

8 Several conversations during my fieldwork reveal what Regina Bendix [1997] discuss as a longing for authenticity, which manifests as a desire to experience and consume cultural practices and styles that are believed to be genuine, as opposed to spurious or modernized versions. I have also had fruitful conversations with Rezidentsiia Baba team members about their developing notions of authenticity. Whereas bright colors used in handmade items like socks and mittens used to signify inauthenticity for one team member, she now sees these innovations as "signs of life" in which change indicates that the tradition is alive.

9 Danille Christensen [2015] challenges the idea of folk revival as merely an appropriation and taming of cultural forms, pointing to the revival of home canning as an identity-affirming practice at the grassroots level in both urban and rural spaces. This is not to say, of course, that a single social imaginary of the village exists - hardly! Rather, I argue that we can read the complexities of folk revival in Bulgaria as much more complicated than merely guided by nationalistic impulses and that revival can point to layered and sometimes conflicting understandings of folklore and authenticity. People living in villages and cities alike hold complex notions of how rural transformation has shaped their identities as Bulgarians and the role of village lifeways in these identities.

10 The original lockdown period was issued for a duration of one month on 13 March but extended to mid-May around the Orthodox Easter holidays. Lockdown measures ebbed and flowed as politicians tried to keep pace with evershifting scientific evidence and their EU neighbors. Political squabbles regarding 
the measures between president Rumen Radev and Prime Minister Boyko Borisov (and their respective parties) also contributed to shifting measures. Measures restricting transportation were relaxed in April and then tightened once more as the Easter holiday neared in anticipation of crowds at midnight services.

11 On 24 March, one friend shared with me that her mother and many others were devastated by measures restricting mobility within Bulgaria. The requirement to live at one's permanent address or place of work had an unintended consequence of keeping many families away from village homes at the time when they would typically be seeding gardens. Her municipality amended their measures to allow residents to apply for special permits to travel to their villages. Ironically, this resulted in long lines at municipal offices and excessive amounts of paperwork for mayors and other staff.

12 This ethnographic sketch draws on daily fieldnotes, interviews conducted during and after lockdown, and conversations with friends and interlocutors. News updates including daily briefings by Major General Ventsislav Mutafchiiski, the face and head of coronavirus operations, also provide context.

13 Correspondence with TD on 15 April 2020.

14 A third project, Priemi Me Na Selo [Accept Me in the Village], takes place in the Gabrovo municipality, but cancelled all 2020 programming outright and thus is not addressed in this paper. It is worth mentioning, though, that this project is municipally funded and, out of the three residencies, most strongly presents village lifeways as heritage - residuals of the way life used to be, rather than an interweaving of contemporary village life with traditional practice.

15 Although this article primarily speaks to the triumphs of emergency adaptation, it is worth noting that one team member framed these new initiatives as unsustainable reactionary work that placed an extreme burden on the Fabrika za Idei team in an already-precarious moment for cultural workers.

16 During a conversation with one of the Rezidentsiia Baba team members, I asked if it felt ironic that they were actively discouraging intergenerational interaction at this time. She responded very energetically that yes, this moment felt very ironic. Their team wanted to create a video campaign in which elderly women told young people not to visit them- "it's funny," she explained, "that now these women are becoming this voice of wisdom, authority, and experience" [fieldnotes 15 April 2020].

17 Boriana, a 2020 participant of Rezidentsiia Baba, reported that she and $B a b a$ Vasilka agreed that this moment changes life more so for young people than for the elderly in villages.

18 I am not claiming that all elderly villagers were wary of visitors from cities, due to the threat of coronavirus. In fact, some villagers (as well as urbanites) I spoke with were skeptical of the virus's existence and critical of the restrictive mobility measures. Rather, I am claiming that in promoting an official position regarding travel to villages, Rezidentsiia Baba made use of certain tactics, including listening to and sharing select elderly voices, to craft its messaging, and that this messaging aligns with its overall philosophy to incorporate and take seriously the desires of the elderly it works with. 
19 This is not to say that there was no state or municipal aid, but rather that projects were able to mobilize quickly and flexibly.

20 Conversation with Selo Nazaem co-founders [Fieldnotes 31 July 2020].

21 This episode of Da khvanesh gorata aired on 21 March 2020. It featured the work of Anelia and Nina during the emergency situation and covered Selo Nazaem more broadly. The NovaTV program, hosted by Galia Shturrbeva, follows and interviews families who move to villages and has become a household name. The views shared in this video were reiterated by personal communications with Anelia and Nina in May and July of 2020.

22 Late in the summer of 2020, I was fortunate to visit Dolni Vadin and have wonderfully fulfilling conversations with Anelia and Nina, as well as outdoor chats with several women who had hosted participants in previous years. I understood from these conversations and interviews that the greatest impact of the Selo Nazaem program to the community is the life, energy, and relationships that these intergenerational residencies have brought to the village.

23 These clips have since expired, though the posts still exist. My field notes record one video that shares tips for starting a garden.

24 Personal communication with Anelia Radulova, 31 July 2020 and 13 March 2021.

25 During the 1990s, rural-urban familial food networks are said to have been a source of survival for many families and continue to serve as a resource as jars of preserves, sauces, and bundles of dried herbs travel to city relatives from village households [Ghodsee 2009, 2011; personal communications with Lindsey Foltz; interviews conducted during 2020]. "Survival" here invokes several meanings. Of course, some village projects stand out as clear instances of heritagization and safeguarding. A number of Bulgarian villages have been transformed into open-air museums for tourism, a (sometimes) lucrative way of commodifying the village space. Others host annual festivals that transform the village space into a temporary stage for heritage performances of song, dance, folk ensembles, food, ritual, and holiday celebrations. In these situations, the idealized rural village is frozen as relic of the past or serves as the backdrop/surround for staging folklore. Still others are home to experimental ecocommunities or small-scale farms, connoting survival that requires adaptation of lifeways, rather than a fixing of practices.

\section{BIBLIOGRAPHY}

Abrahams, Roger D. 2005. "Zones and Borders," in Everyday Life: A Poetics of Vernacular Practices. Pittsburgh, PA: University of Pennsylvania Press.

Ben-Amos, Dan. 1971. "Toward a New Definition of Folklore in Context," Journal of American Folklore 84 (331): 3-15.

Bendix, Regina. 1997. In Search of Authenticity: The Formation of Folklore

Studies. Madison, WI: University of Wisconsin Press. 
Bendix, Regina, Kilian Bizer, and Dorothy Noyes. 2017. Sustaining Interdisciplinary Collaboration: A Guide for the Academy. Champaign, IL: University of Illinois Press.

Brave the Village. n.d. "Смело на село" [Brave the Village], WordPress. Cited by https://gotothevillage.wordpress.com/. (consulted 8 May 2021).

Buchanan, Donna. 2006. Performing Democracy: Bulgarian Music and Musicians in Transition. Chicago, IL: University of Chicago Press.

Bucholtz, Mary. 2002. "Youth and Cultural Practice," Annual Review of Anthropology 31:525-52.

Christensen, Danille. Simply Necessity? 2015. "Agency and Aesthetics in Southern Home Canning," Southern Cultures. 21 (1):15-42.

Creed, Gerald W. 1998. Domesticating Revolution: From Socialist Reform to Ambivalent Transition in a Bulgarian Village. University Park, PA: Pennsylvania State University Press.

Creed, Gerald W. 2013. "Every Village, A Different Story: Tracking Rural Diversity in Bulgaria," in Global Villages: Rural and Urban Transformations in Contemporary Bulgaria. London: Anthem Press.

Dimitrova, Petya. 2019. "Exploring Sustainability with Urban-Rural Migrants: An Ethnographic

Experience in Poland," EthnoAnthropoZoom/ЕтноАнтропоЗум 17 (November): 193227.

Duijzings, Gerlachlus, ed. 2013. Global Villages: Rural and Urban Transformations in Contemporary Bulgaria. London: Anthem Press.

Filak, Manca, dir. 2015. Заграбване на Земята [Land Grabbing]. Cited by: https://www.youtube.com/watch?v=43oxXW1G2NE\&fbclid=IwAR0n71Bt 7ejS5LMi7ozOQwmVhGSnPZbFGfOV SdcqPF63zNdmI-hMiAqlyI. (consulted 26 December 2020).

Gavrailov, Gavrail, Mikhail Mihov, and Anna Pelova. 2016. Гавраилов Гавраил, Михаил Михов, и Анна Пелова. Села И Туризъм: Посоки $3 a$ Пътешествия Из България [Villages and Tourism: Travel Directions Around Bulgaria]. Sofia: Ciela.

Ghodsee, Kristen Rogheh. 2009. Muslim Lives in Eastern Europe: Gender, Ethnicity, and the Transformation of Islam in Postsocialist Bulgaria. Princeton: Princeton University Press.

Ghodsee, Kristen Rogheh. 2011. Lost in Transition: Ethnographies of Everyday Life After Communism. Durham: Duke University Press.

Hafstein, Valdimar. 2012. "Heritage," in A Companion to Folklore, Regina Bendix and Galit Hasan-Rokem, eds. Hoboken: Blackwell Publishing.

Kaneff, Deema. 2004. Who Owns the Past?: The Politics of Time in a 'Model' Bulgarian Village. London: Berghahn Books.

Kaneff, Deema. 2013. "Rural-Urban Relations in a Global Age," in Global Villages: Rural and Urban Transformations in Contemporary Bulgaria, Gerlachlus Duijzings, ed. London: Anthem Press.

Katracheva, Ekaterina. 2020. Катрачева Екатерина. "В Долни Вадин доставят на възрастните хора храна, лекарства и книги” [In Dolni Vadin They 
Deliver Food, Medicine, and Books to Elderly People], Darik Radio. Cited by: https://darikradio.bg/v-dolni-vadin-dostavat-na-vazrastnite-hora-hranalekarstva-i-knigi.html. (consulted 26 December 2020).

MacDermott, Mercia. 1998. Bulgarian Folk Customs. London: Jessica Kingsley Publishers.

Neuberger, Mary. 2013. Balkan Smoke: Tobacco and the Making of Modern Bulgaria. Ithaca: Cornell University Press.

Noyes, Dorothy. 2016. Humble Theory: Folklore's Grasp on Social Life. Bloomington: Indiana University Press.

Rezidentsiia Baba. 2020a. Резиденция Баба. "Баба Вили от с. Синаговци / устойчвост в извънредно положение" [Baba Vili from village Sinagovtsi/stability in state of emergency]. Facebook. Cited by https://www.facebook.com/604304183004311/videos/233612721151398.

(consulted 21 March 2021).

Rezidentsiia Baba. 2020b. Резиденция Баба. "Баба Василка от с. Синаговци как да се чувстваме по-добре в този период” [Baba Vasilka from village Sinagovtsi - how to feel better in this period]. Facebook. Cited by https://www.facebook.com/BabaResidence/videos/214205349833592.

(consulted 3 April 2020; 26 December 2020).

Rezidentsiia Baba. 2020c. Резиденция Баба. “Баба знае че” [Baba Knows That], Facebook. Cited

https://www.facebook.com/BabaResidence/photos/2351617374939641.

(consulted 26 December 2020).

Rezidentsiia Baba. 2020d. Резиденция Баба. "Резиденция Баба съвет номер 1"

[Rezidentsiia Baba advice number 1]. Facebook. Cited by https://www.facebook.com/BabaResidence/photos/2369812019786843.

(consulted 8 May 2021).

Silverman, Carol. 1983. "The Politics of Folklore in Bulgaria," Anthropological Quarterly 56 (2): 55-61.

Spasova, Anelia. 2020. Спасова Анелия. "Село назаем - Долни Вадин” [Borrowed Village - Dolni Vadin]. Facebook. Cited by https://www.facebook.com/groups/104705926638076. (consulted 26 December 2020).

Stoianova, Ioana. 2016а. Стоянова Йоана. "Резиденция Баба / Baba Residence." Facebook. Cited by https://www.facebook.com/BabaResidence/?ref=page internal. (consulted 26 December 2020).

Stoianova, Ioana. Стоянова Йоана. 2016b. Фабрика за Идеи [Ideas Factory]. Ideasfactorybg. Cited by https://ideasfactorybg.org/en/. (consulted 26 December 2020).

Stoyanova V., N. Karlezhova, D. Popcheva, S. Ilieva, A. Ivanova, Kr. Petkova, and D. Vukovska. 2020. В. Стоянова, Н. Кьрлежова, Д. Попчева, С. Илиева, А. Иванова, Кр. Петкова, Д. Вуковска. Population and Demographic Processes 2019. National Statistics Institute, Sofia, Bulgaria. Cited 
https://www.nsi.bg/sites/default/files/files/publications/DMGR2019.pdf (consulted 26 December 2020).

Stewart, Susan. 1991. "Notes on Distressed Genres," The Journal of American Folklore 104 (411): 5-31.

Shtŭrbeva, Galia. 2020 Щьрбева Галя. ““Да хванеш гората': Младите в помощ на пенсионерите в с. Долни Вадин” [“То Catch the Forest”: Young people helping pensioners in the village of Dolni Vadin]. Nova.bg. Cited by https://nova.bg/news/view/2020/03/21/282213/да-хванеш-горатамладите-в-помощ-на-пенсионерите-в-с-долни-вадин/. (consulted 26 December 2020).

Todorova, Maria, and Zsuzsa Gille. 2010. Post-Communist Nostalgia. London: Berghahn Books.

Toelken, Barre. 1996. The Dynamics of Folklore. Logan: Utah State University Press.

United Nations, Department of Economic and Social Affairs, Population Division (2019). World Population Prospects 2019: Highlights. ST/ESA/SER.A/423. Verdery, Katherine. 2003. The Vanishing Hectare: Property and Value in Postsocialist Transylvania. Ithaca: Cornell University Press.

The Village in Transition. n.d. Селото в преход. Facebook. Cited by https://www.facebook.com/selotovprehod/. (consulted 8 May 2021). 